\title{
АНАЛІЗ МОЖЛИВОСТІ ФІНАНСУВАННЯ ДІЯЛЬНОСТІ МАЛОГО ТА МІКРОБІЗНЕСУ ХАРКІВСЬКОЇ ОБЛАСТІ ШЛЯХОМ ЗАЛУЧЕННЯ МІЖНАРОДНОГО ФІНАНСОВОГО КАПІТАЛУ
}

\section{ANALYSIS OF THE POSSIBILITY \\ OF FINANCING SMALL AND MICROBUSINESS ACTIVITIES OF THE KHARKIV REGION BY INVOLVING INTERNATIONAL FINANCIAL CAPITAL}

\author{
Чемчикаленко Руслан Анатолійович \\ кандидат економічних наук, доцент, \\ Харківський національний університет імені В.Н. Каразіна \\ ORCID: https://orcid.org/0000-0003-1064-0864 \\ Chemchykalenko Ruslan \\ V.N. Karazin Kharkiv National University
}

\begin{abstract}
Стаття присвячена дослідженню можливостей фрінансування діяльності малого та мікробізнесу Харківської області шляхом залучення міжнародного фрінансового капіталу. Проаналізовано динаміку прямих інвестицій як в Україну, так і за її межі за рахунок використання боргових інструментів. Досліджено роль і значення основних міжнародних фрінансових центрів. Проаналізовано діяльність міжнародних фрінансово-кредитних організацій, що діють в Україні. Досліджено можливість використання коштів грантових донорських програм для фрінансування діяльності малого та мікробізнесу Харківської області. Доведена можливість можливості використання альтернативних інструментів міжнародного фрінансування 3 метою вирішення проблеми фрінансування вітчизняного бізнесу як з огляду на подовження часу залучення кредитних коштів, так і здешевлення їх вартості.
\end{abstract}

Ключові слова: джерело фрінансування бізнесу, малий та мікробізнес, інвестиції, фрінансовий центр, міжнародні фрінансово-кредитні організації.

Статья посвящена исследованию возможностей фринансирования деятельности малого и микробизнеса в Харьковской области путем привлечения международного фринансового капитала. Проанализирована динамика прямых инвестиций как в Украину, так и за ее пределы за счет использования долговых инструментов. Исследованы роль и значение основных международных фринансовых центров. Проанализирована деятельность международных фринансово-кредитных организаций, действующих в Украине. Исследована возможность использования средств грантовых донорских программ для фринансирования деятельности малого и микробизнеса Харьковской области. Доказана возможность использования альтернативных инструментов международного фринансирования с целью решения проблемы фринансирования отечественного бизнеса как с учетом продления времени привлечения кредитных средств, так и удешевления их стоимости.

Ключевые слова: источник финансирования бизнеса, малый и микробизнес, инвестиции, сринансовый центр, международные фринансово-кредитные организации.

The article is devoted to the research of possibilities of financing the activity of small and microbusiness of Kharkiv region by attracting international financial capital. The dynamics of direct investments both in Ukraine and abroad due to the use of debt instruments is analyzed. It was found that due to the size and features of the used organizational and legal forms of small and micro businesses, as a rule, do not use such a tool as investing in equity. Assessing the real inflows of investments in the form of debt obligations to the Kharkiv region, it is established that their volumes are insignificant, even on a domestic scale. At the same time, their structure does not correspond to the global distribution of financial centers, which is due to the offshore nature of most investment agreements. Regarding the sectoral structure of distribution of funds invested in Ukraine, it was found that the vast majority of them fall on industry with a share of $49.11 \%$ and wholesale and retail trade $-14.08 \%$. The activity of international financial and credit organizations operating in Ukraine is analyzed. In particular, the characteristics of the programs of the 
International Finance Corporation, the European Bank for Reconstruction and Development, the German State Development Bank, the German-Ukrainian Fund. It is established that this mechanism of attracting foreign funds is not used enough. At the same time, the list of international business financing programs in Ukraine still remains insignificant. It is proposed to use the funds of grant programs as alternative tools for international financing of small and micro businesses. The basic requirements for participation in such grant programs as "Grant competition for startups and social enterprises Synergy for Change", "Second wave of grant competition for the implementation of civic tech tools in a pandemic", "Grants + Visegrad Fund for the Western Balkans and Eastern Partnership countries" are listed, "Coronavirus Fast Response Fund. Black Sea Trust for Regional Cooperation". It is established that the use of grant programs to solve the problem of financing domestic business has a positive effect on extending the time of borrowing and reducing their cost.

Keywords: source of business financing, small and microbusiness, investments, financial center, international financial and credit organizations.

Постановка проблеми. В сьогоднішніх умовах вітчизняні фрінансово-кредитні установи не готові повною мірою фрінансувати малий та мікробізнес, тому значна роль щодо кредитування відповідного бізнесу покладається на міжнародні фрінансові інституції. Отримати кошти від них - процес доволі складний, однак вигідний для підприємців, оскільки сума кредиту може бути достатньо великою, а відсотки за кредит - навпаки, меншими, за запропоновані фрінансово-кредитними установами України.

Аналіз останніх досліджень і публікацій. Проблематиці фрінансування малого та мікробізнесу присвячені праці низки як українських, так і зарубіжних фрахівців, серед яких можна відзначити роботах О. Барановського, 3. Варналія, Т. Васильцев, Ю. Галіцейської, О. Дзюблюк, С. Іванова, Н. Захарченко, Д. Омарової, Ю. Клочко, Р. Корнилюк, А. Корнилюк, В. Кредисова, І. Холоменюка, В. Черненко, В.В. Черняка та багатьох інших.

Виділення невирішених раніше частин загальної проблеми. Проте, динамізм й нестабільність вітчизняної економіки в цілому, а також зростання ролі й значення глобалізаційних процесів, в тому числі й в сорері міжнародної фрінансової діяльності, змушують нас по-новому подивитися на дану проблематику й шукати оптимальні джерела фрінансування передусім для малого й мікробізнесу з урахуванням реальної ситуації й сьогоднішніх можливостей ринку.

Формулювання цілей статті (постановка завдання). Метою статті $є$ дослідження можливості залучення, а також проблем і переваг використання міжнародного фрінансового капіталу для фрінансування діяльності малого та мікробізнесу Харківської області .

Виклад основного матеріалу дослідження. В свою чергу аналіз прямих інвестицій 3 залученням боргових інструментів (інвестування в акціонерний капітал ми не розглядаємо, оскільки малий та мікробізнес, як правило, обирає такі організаційно-правові фрорми, за умови використання яких вони не можуть користатися можливостями залучення коштів за рахунок випуску акцій) показує, що притік інвестиційних коштів $€$ відносно невеликим, проте в десятки разів більший за відтік з України інвестиційних коштів за аналогічний період (рисунок 1).

Оцінюючи реальні надходження інвестицій в вигляді боргових зобов'язань, що приходяться на Харківську область, необхідно констатувати мізерність їх обсягів навіть в вітчизняних масштабах. В структурі загальних інвестицій по країні на Харківщину станом на 31.12.2019 р. приходилось всього 2,35\% від загального їх обсягу, тоді як на лідерів (м. Київ, Одеську та Донецьку області) приходилось в сумі майже $60 \%(39,04 \%, 11,44 \%$ та 9,25\% відповідно).

Тому підприємствам Харківщини за потреби залучення додаткового капіталу варто звернути увагу на інші джерела фрінансових коштів, зокрема, міжнародні.

В світі існує декілька міжнародних фрінансових центрів, які можуть фрінансувати міжнародні проекти практично будь-якого рівня. Чільна десятка фрінансових центрів має такий вигляд: Лондон, Нью-Йорк, Гонконг, Сінгапур, Шанхай, Токіо, Чикаго, Цюрих, СанФранциско, Торонто [2].

Першим і найважливішим є Лондонський міжнародний фрінансовий центр. Це один 3 найбільших центрів торгівлі іноземною валютою, цей ринок щороку зростає на $39 \%$, що швидше ніж у Нью-Йорка з його приростом в 8\%. Практично 80\% європейських хеджфондів керується з Лондона, при тому, що середня норма їх прибутковості в 2010 році складала 16\% - майже в два рази більше, ніж у хедж-фрондів в США.

Нью-Йоркський міжнародний фрінансовий центр залишається одним 3 найкрупніших фрінансових центрів світу. В 2010 році іноземні інвестиції в США складали 194 млрд. дол. 


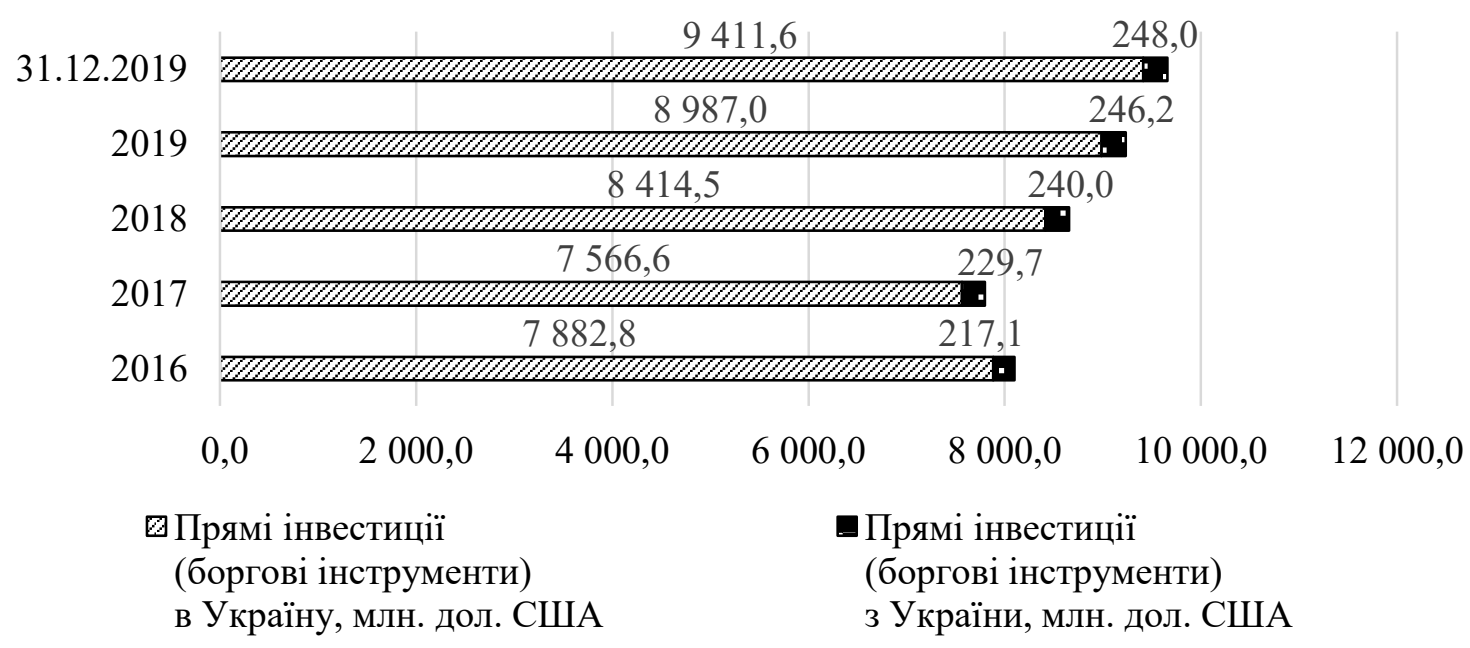

Рис. 1. Прямі інвестиції (боргові інструменти)

Джерело: складено автором за [1]

США. На світовому ринку хеджпослуг НьюЙорк все ще залишається лідером - серед 50 найбільших хедж-компаній, 18 знаходяться у Нью-Йорку. Нью-Йорк займає друге місце в світі за розміром обігу валюти - щоденні обсяги валютних операцій на ринку біля 500 млрд. дол. США.

Сінгапурський міжнародний фрінансовий центр. Сінгапур є другим серед найбільших центрів, що спеціалізуються на позабіржовій торгівлі вторинними цінними паперами в Азії. Ця країна єдина в Азії країна, яка має кредитний рейтинг AAA у всіх трьох найбільших кредитно-рейтингових агентств Standard\&Poor's, Moody's та Fitch.

Гонконгський міжнародний фрінансовий центр $€$ четвертим за величиною світовим фрінансовим центром, дев'ятою за величиною економікою світу й займає одинадцяте місце в списку найбільших експортерів послуг. Зовнішні активи гонкогського банківського сектора займають п'яте місце в світі за обсягом, за обсягом обміну валют - шосте місце в світі, а фрондовий ринок $є$ найбільшим у Азії за рівнем капіталізації після такої країни даного регіону як Японія [2, с. 20-21].

В той же час оцінюючи геограсрічну структуру інвестування в економіку нашої країни картина виглядає дещо по-іншому. На кінець 2019 року левова частка коштів (52,36\% від загального обсягу коштів інвестованих в нашу країну у вигляді боргових інструментів) припадала на Кіпр, який має статус офршорної зони, тоді як частка Сполученого Королівства Великої Британії та Північної Ірландії склала всього 1,88\%, США - 0,67\%, Гонконгу - 0,05\%, Сінгапуру - 0,16\%. Відповідно чітко простежу- ється проста репатріація тіньових прибутків вітчизняних підприємств [1].

В галузевій структурі інвестованих в Україні коштів $з$ допомогою боргових інструментів все ж таки переважає промисловість з часткою в 49,11\% від загального їх обсягу, в тому на сектор машинобудування припадає 3,90\%, тоді як на сільське, лісове та рибне господарство $-2,60 \%$, а на оптову та роздрібну торгівлю - 14,08\%.

Як бачимо географрічна структура інвестування в економіку країни з використанням боргових інструментів свідчить про недостатню розповсюдженість цього механізму залучення іноземних коштів. До того ж й перелік програм міжнародного фрінансування бізнесу в Україні до сих пір залишається не таким великим (таблиця 1).

При цьому необхідно відзначити, що, наприклад, вимоги Європейського банку реконструкції та розвитку є доволі прийнятними й для досліджуваного класу підприємств (таблиця 2).

Можливим альтернативним джерелом фрінансування бізнесу, в тому числі такого, що реалізується на міжнародному рівні, $€$ використання коштів грантових донорських програм (таблиця 3).

Так, мікро-, малі та середні підприємства мають можливість брати участь у грантових програмах, та отримувати безповоротну допомогу для розвитку бізнесу у фрінансовій та /або нефрінансовій фрормі.

Оцінюючи реальну активність в цьому напрямку підтримки малого та середнього бізнесу в 2020 році в Харківській області необхідно відзначити, що допомога здійснювалась 
Таблиця 1

Міжнародні фрінансово-кредитні організації, що діють в Україні

\begin{tabular}{|c|c|c|}
\hline \begin{tabular}{|c|} 
Міжнародні \\
фрінансові організації
\end{tabular} & Назва програми & Опис програми \\
\hline 1 & 2 & 3 \\
\hline \multirow{5}{*}{$\begin{array}{l}\text { Міжнародна } \\
\text { фінансова корпорація } \\
\text { (International Finance } \\
\text { Corporation) }\end{array}$} & $\begin{array}{l}\text { Ukraine Sustainable } \\
\text { Energy Finance } \\
\text { Program }\end{array}$ & $\begin{array}{l}\text { Метою програми є забезпечення фрінансами та } \\
\text { підтримка бізнесу, діяльність якого спрямована } \\
\text { на енергоефрективність. }\end{array}$ \\
\hline & $\begin{array}{l}\text { Ukraine Resource } \\
\text { Efficiency Program }\end{array}$ & $\begin{array}{l}\text { Метою програми є збільшення кількості } \\
\text { інвестицій в бізнес та ресурсозберігаючі } \\
\text { технології }\end{array}$ \\
\hline & \begin{tabular}{|l} 
IFC Ukraine \\
Residential Energy \\
Efficiency Project
\end{tabular} & $\begin{array}{l}\text { Метою програми є фрінансування модернізації } \\
\text { житлового сектору за рахунок використання } \\
\text { економічних енерготехнологій }\end{array}$ \\
\hline & $\begin{array}{l}\text { Ukraine Agri- } \\
\text { Insurance } \\
\text { Development Project }\end{array}$ & $\begin{array}{l}\text { Програма спрямована на підтримку та } \\
\text { розвиток страхування агробізнесу. Програма } \\
\text { фрінансується за підтримки Міністерства } \\
\text { закордонних справ, торгівлі та розвитку } \\
\text { Канади }\end{array}$ \\
\hline & $\begin{array}{l}\text { Ukraine Agri-Finance } \\
\text { Project }\end{array}$ & $\begin{array}{l}\text { Програма має за мету фрінансування } \\
\text { агробізнесу та підтримку } \\
\text { сільськогосподарського виробництва в Україні. }\end{array}$ \\
\hline \multirow{2}{*}{$\begin{array}{l}\text { Європейський } \\
\text { банк реконструкції } \\
\text { та розвитку } \\
\text { (European Bank for } \\
\text { Reconstruction and } \\
\text { Development (EBRD) }\end{array}$} & \begin{tabular}{|l|} 
The Eastern \\
Partnership SME \\
Finance Facility \\
\end{tabular} & $\begin{array}{l}\text { Метою програми є кредитування малого і } \\
\text { середнього бізнесу в умовах фрінансової кризи }\end{array}$ \\
\hline & ЄБРР & $\begin{array}{l}\text { Метою програми є кредитування бізнесу в } \\
\text { Україні незалежно від розміру }\end{array}$ \\
\hline $\begin{array}{l}\text { Німецький державний } \\
\text { банк розвитку (KfW) }\end{array}$ & $\begin{array}{l}\text { European Fund for } \\
\text { Southeast Europe }\end{array}$ & $\begin{array}{l}\text { Метою програми є широкий спектр } \\
\text { фрінансування бізнесу }\end{array}$ \\
\hline \multirow[b]{2}{*}{$\begin{array}{l}\text { Німецько-український } \\
\text { фронд }\end{array}$} & $\begin{array}{l}\text { Програма } \\
\text { мікрокредитування }\end{array}$ & $\begin{array}{l}\text { Відповідно до програми максимальний розмір } \\
\text { кредиту становить € } 25000 \text { (для фрізичних } \\
\text { осіб - підприємців і мікропідприємств), € } 100 \\
\text { 000 (для малих підприємств), € } 250 \text { о00 (для } \\
\text { середніх підприємств). Термін кредитування: } 3 \\
\text { роки - для ффінансування оборотного капіталу; } \\
5 \text { років - для фінансування інвестицій в } \\
\text { основні засоби. }\end{array}$ \\
\hline & $\begin{array}{l}\text { Програма } \\
\text { ресрінансування } \\
\text { агросектору }\end{array}$ & $\begin{array}{l}\text { Метою програми є фрінансування виробництва, } \\
\text { агробізнесу, торгівлі та сфери послуг. } \\
\text { Основною умовою участі в програмі } \\
\text { підприємців є те, що кредитування поширене } \\
\text { на малий та середній бізнес у місцевості, де } \\
\text { чисельність населення не перевищує } 100 \\
\text { тис. Відповідно до програми, максимальний } \\
\text { розмір кредиту становить є 250000. Термін } \\
\text { кредитування за умовами програми становить } \\
\text { 3 роки (для фрінансування оборотного капіталу) } \\
\text { та } 5 \text { років (для фрінансування інвестицій в } \\
\text { основні засоби) }\end{array}$ \\
\hline
\end{tabular}

Джерело: [3, с. 120]

в рамках проектів та програм міжнародної технічної та іншої фрінансової допомоги, зокрема у рамках реалізації пілотного проекту «Рука допомоги» відповідно до постанови Кабінету Міністрів України від 02.12.2015 № 1154 «Про реалізацію пілотного проекту із залучення до роботи членів малозабезпечених сімей та внутрішньо переміщених осіб» у межах реалізації МБРР проекту «Модернізація системи соціальної підтримки населення України».

У 2019 році в Харкові Європейський банк реконструкції та розвитку та Центр інорормаційної підтримки бізнесу (м. Харків, заснований на базі Харківської торгово-промислової 
Критерії відповідності одержувача позики вимогам ЄБРР

Таблиця 2

\begin{tabular}{|l|l|}
\hline \multicolumn{1}{|c|}{ Критерій } & \multicolumn{1}{c|}{ Вимоги ЄБРР } \\
\hline Кількість працівників & Не більше 500 осіб \\
\hline Частка недержавної власності, \% & Не менше 50 \\
\hline $\begin{array}{l}\text { Допроектні активи (за винятком вартості } \\
\text { споруд, будівель та земельних ділянок) }\end{array}$ & Не більше 2,5 млн дол. СшА \\
\hline $\begin{array}{l}\text { Співвідношення займаних і власних коштів } \\
\text { (з урахуванням кредиту ЄБРР) }\end{array}$ & Не більше ніж $70: 30$ \\
\hline Сума (враховуючи 1 \% комісійних), дол. США & Від 50 тис. до 2,5 млн \\
\hline Термін & $\begin{array}{l}\text { Короткостроковий - від } 6 \text { до } 12 \text { міс. } \\
\text { Довгостроковий - до 5 років }\end{array}$ \\
\hline Забезпечення & $\begin{array}{l}\text { Вартість застави не менше 120 \% } \\
\text { від основної суми боргу та відсотків }\end{array}$ \\
\hline Вартість проекту, дол. СшА & Від 75 тис. до 4 млн \\
\hline Внесок позичальника у проект & Не менше 30 \% від вартості проекту \\
\hline
\end{tabular}

Джерело: [4]

\section{Донорські програми за якими передбачено фрінансова допомога у вигляді грантів для сфери виробництва та торгівлі}

\begin{tabular}{|c|c|c|c|}
\hline Назва і сутність програми & Термін дії & Виконавець, контакти & $\begin{array}{c}\text { Можливий обсяг } \\
\text { фрінансування }\end{array}$ \\
\hline $\begin{array}{l}\text { Грантовий конкурс для } \\
\text { стартапів та соціальних } \\
\text { підприємств Synergy } \\
\text { for Change (втілення } \\
\text { інноваційних проєктів для } \\
\text { сталого розвитку) } \\
\end{array}$ & 23/05/2021 & $\begin{array}{l}\text { Synergy for Change } \\
\text { synergy.d.consulting@ gmail. } \\
\text { com }\end{array}$ & $\begin{array}{l}3 \text { місця від €4000 } \\
\text { до €10000 }\end{array}$ \\
\hline \begin{tabular}{|l|} 
Друга хвиля конкурсу \\
грантів на впровадження \\
інструментів сіvіс tech \\
в умовах пандемії \\
(впровадження використання \\
інструментів сіvіс tech на \\
місцевому/регіональному \\
рівні)
\end{tabular} & $12 / 05 / 2021$ & $\begin{array}{l}\text { Фонд Східна Європа } \\
\text { 3DProject@eef.org.ua }\end{array}$ & $\begin{array}{l}\text { до } 550000 \\
\text { грн для однієї } \\
\text { організації }\end{array}$ \\
\hline \begin{tabular}{|l|} 
Гранти+ Вишеградського \\
Фонду Для Західних \\
Балкан Та Країн Східного \\
Партнерства (Збільшення \\
В2В Мереж 3 Акцентом На \\
Розвиток МСП Та Стартапів)» \\
\end{tabular} & Безстроково & $\begin{array}{l}\text { Visegrad Fund } \\
\text { https://www.visegradfund. org/ } \\
\text { about-us/the-fund/ }\end{array}$ & $\begin{array}{l}\text { до 100\% бюджету } \\
\text { проєкту з 15\% на } \\
\text { накладні витрати }\end{array}$ \\
\hline \begin{tabular}{|l} 
Фонд швидкого \\
реагування на Корона- \\
вірус. Чорноморський \\
траст регіональ-ного \\
співробітництва (Coronavirus \\
Fast Response Fund. Black \\
Sea Trust for Regional \\
Coоperation) (швидка \\
допомога вразливим групам \\
для запобігання подальшого \\
поширення вірусу)
\end{tabular} & Безстроково & $\begin{array}{l}\text { Black Sea Trust for Regional } \\
\text { Cooperation } \\
\text { https://bit.ly/2UtTO6U }\end{array}$ & $\begin{array}{l}\text { до } 25 \text { тис. } \\
\text { доларів США }\end{array}$ \\
\hline
\end{tabular}

Таблиця 3 
палати), за підтримки ЄБРР у рамках ініціативи $€ C$ EU4Business, провели для представників малих та середніх підприємств презентацію «Можливості для розвитку МСБ від ЄБРР».

3 метою поліпшення фрінансового клімату малого і середнього бізнесу, Департаментом економіки і міжнародних відносин Харківської обласної державної адміністрації, Харківським регіональним фрондом підтримки підприємництва та Німецько-Українським фрондом розроблено механізм часткового відшкодування відсоткових ставок за кредитами банків для суб'єктів малого та середнього підприємництва в Харківській області, затверджений рішенням XVIII сесії Харківської обласної ради VII скликання від 06 грудня 2018 року № 835-VII.

Порядок часткового відшкодування відсоткових ставок по кредитам банків визначає механізм часткової компенсації з обласного бюджету відсоткових ставок за кредитами, що надаються банками-партнерами Німецько-Українського фронду на реалізацію Програми сприяння розвитку малого й середнього підприємництва в Харківській області на 2016-2020 роки.

Проте альтернативи залучення іноземних коштів $€$ і в Україні.

Так відповідно до постанови КМУ «Про внесення змін до Порядку надання державної підтримки суб'єктам мікропідприємництва та малого підприємництва» вдосконалено механізм Державної програми «Доступні кредити «5-7-9\%», відповідно до якої передбачено надання коштів 3 максимальною сумою кредиту в до 2 млн грн. При цьому передба- чено розширення інвестиційних цілей, на які можуть бути надані кредити за цим Порядком: набуття комерційної нерухомості без права її передачі платне чи безоплатне користування третіми особами; набуття на платній основі об'єктів прав інтелектуальної власності відповідно до договорів комерційної концесії (фрранчайзинга), що пов'язані 3 реалізацією суб'єктами підприємництва інвестиційних проектів; поповнення оборотного капіталу суб'єктів підприємництва в розмірі не більше $25 \%$ від загальної вартості інвестиційного проекту, який фрінансується кредитним коштом.

Відповідно до даної Постанови також передбачено збільшення до 35\% рівня максимальної суми сплати за гарантією Фонду розвитку підприємництва 3 відповідним збільшенням допустимого рівня частки проблемної заборгованості за кредитами, наданими новоствореним суб'єктам підприємництва, до 25\% [5].

Висновки. Таким чином, оцінюючи фрактичний стан справ 3 фрінансуванням малих i мікропідприємств-суб'єктів міжнародного бізнесу необхідно відзначити, що проведений аналіз стану залучення інвестиційних коштів в Україну та Харківську область, а також аналіз фрункціонуючих на ринку міжнародних фрінансово-кредитних інституцій та донорських грантових програм, дає нам право стверджувати існування можливості використання відповідних інструментів міжнародного фрінансування 3 метою вирішення проблеми фрінансування вітчизняного бізнесу як з огляду на подовження часу залучення кредитних коштів, так і здешевлення їх вартості.

\section{СПИСОК ВИКОРИСТАНИХ ДЖЕРЕЛ:}

1. Публікація документів Державної Служби Статистики України. URL: http://ukrstat.org/uk/operativ/oper_ new.html

2. Галіцейська Ю. М. Міжнародні ринки грошей і капіталів : навчальний посібник. Тернопіль : Вектор, 2013. 219 c.

3. Холоменюк І. М. Джерела та проблеми фрінансування розвитку малого та середнього бізнесу: вітчизняний та закордонний досвід. Науковий вісник Міжнародного гуманітарного університету. 2016. Випуск 16. С. 119-122.

4. Гриньова В. М. Інвестування : підручник. Київ : Знання, 2008. 452 с.

5. Дешеві кредити для бізнесу сталі доступніші: Уряд прийняв рішення. URL: https://biz.ligazakon.net/ news/193839_deshev-krediti-dlya-bznesu-stal-dostupnsh-uryad-priynyav-rshennya

6. Донорські програми. URL: https://sme.gov.ua/program_type/programy-mizhnarodnoyi-tehnichnoyidopomogy/page/2/

7. Національна платсрорма малого та середнього бізнесу. URL: https://platforma-msb.org/category/donorymsb/grantovi-programy/

8. Перелік грантів для малого та середнього бізнесу. Донорські програми. URL: https://shepetivka-rada.gov.ua/ perelik-grantiv-dlya-malogo-ta-serednogo-biznesu-2/ 


\section{REFERENCES:}

1. Publikatsiya dokumentiv Derzhavnoyi Sluzhby Statystyky Ukrayiny [Publication of documents of the State Statistics Service of Ukraine]. Available at: http://ukrstat.org/uk/operativ/oper_new.html

2. Halitseiska Yu. (2013) Mizhnarodni rynky hroshey i kapitaliv [International money and capital markets]. navchal'nyy posibnyk [tutorial]. Ternopil: Vektor, 219 p. (in Ukrainian)

3. Kholomeniuk I. M. (2016) Dzherela ta problemy finansuvannya rozvytku maloho ta seredn'oho biznesu : vitchyznyanyy ta zakordonnyy dosvid [Sources and problems of financing the development of small and medium business: domestic and foreign experience]. Naukovyy visnyk Mizhnarodnoho humanitarnoho universytetu, no. 16, pp. 119-122.

4. Hryn'ova V. M. (2008) Investuvannya [Investment]: pidruchnyk [textbook]. Kyiv: Znannya, 452 p. (in Ukrainian)

5. Deshevi kredyty dlya biznesu stali dostupnishi: Uryad pryynyav rishennya [Cheap business loans have become more affordable: The government has made a decision]. Available at: https://biz.ligazakon.net/news/ 193839_deshev-krediti-dlya-bznesu-stal-dostupnsh-uryad-priynyav-rshennya

6. Donors'ki prohramy [Donor programs]. Available at: https://sme.gov.ua/program_type/programy-mizhnarodnoyi-tehnichnoyi-dopomogy/page/2/

7. Natsional'na platforma maloho ta seredn'oho biznesu [National platform for small and medium business]. Available at: https://platforma-msb.org/category/donory-msb/grantovi-programy

8. Perelik hrantiv dlya maloho ta seredn'oho biznesu. Donors'ki prohramy [List of grants for small and medium businesses. Donor programs]. Available at: https://shepetivka-rada.gov.ua/perelik-grantiv-dlya-malogo-ta-serednogo-biznesu-2/ 